\title{
In situ oxygen isotope micro-analysis of faunal material and human teeth using a SHRIMP II: a new tool for palaeo-ecology and archaeology
}

\author{
Maxime Aubert ${ }^{\mathrm{a}, \mathrm{b}, \mathrm{c}, *}$, Ian S. Williams ${ }^{\mathrm{c}}$, Katarina Boljkovac ${ }^{\mathrm{c}}$, Ian Moffat ${ }^{\mathrm{c}, \mathrm{d}}$, Marie-Hélène Moncel ${ }^{\mathrm{e}}$, \\ Elise Dufour ${ }^{\mathrm{f}}$, Rainer Grün ${ }^{\mathrm{c}}$ \\ ${ }^{a}$ Centre for Archaeological Science, School of Earth E Environmental Sciences, University of Wollongong, Building 41, Northfields Avenue, Wollongong, NSW 2522, Australia \\ ${ }^{\mathrm{b}}$ Universidad de Tarapacá, Depto de Antropologia, 18 de Septiembre 2222, Casilla 6D, Arica, Chile \\ ${ }^{\mathrm{c}}$ Research School of Earth Sciences, Australian National University, Canberra, ACT 0200, Australia \\ ${ }^{\mathrm{d}}$ Department of Archaeology, Flinders University, GPO Box 2100, Adelaide 5001, South Australia, Australia \\ e Département de Préhistoire du Muséum National d'Histoire Naturelle, UMR 7194, CNRS 1, rue René Panhard, 75013 Paris, France \\ ${ }^{\mathrm{f}}$ Muséum national d'histoire naturelle, Archéozoologie, Archéobotanique sociétés, pratiques, environnement, UMR 7209,55 rue Cuvier, 75231 Paris, France
}

\section{A R T I C L E I N F O}

\section{Article history:}

Received 16 March 2011

Received in revised form

18 April 2012

Accepted 3 May 2012

\section{Keywords:}

Oxygen isotopes

Micro-analysis

Palaeo-ecology

Archaeology

Sensitive High Resolution Ion MicroProbe

Secondary ion mass spectrometry

Tooth enamel

Otolith

\begin{abstract}
A B S T R A C T
A Sensitive High Resolution Ion MicroProbe (SHRIMP II) has been used to make high spatial resolution in situ micro-analyses of oxygen isotopes in fish otoliths, and teeth from fossil herbivores and a Neanderthal. Large intra-tooth variations in the oxygen isotopic composition (up to $9 \%$ ) were observed in the enamel of herbivores from the Neanderthal fossil site of Payre, consistent with preservation of seasonal cyclicity. The range of isotopic compositions observed in Neanderthal tooth enamel was much smaller $(\sim 3 \%)$, possibly the result of a longer enamel maturation time averaging out variability. An archaeological otolith from a Preceramic site in Northern Peru exhibited marked changes in $\delta^{18} \mathrm{O}$ over life, due either to the fish occasionally migrating from the sea to a lower salinity habitat, or to short-lived rises in sea water temperature. A fish otolith from Australia's Willandra Lakes World Heritage Area showed clear seasonal variations, but also a general trend towards isotopically heavier and more saline water, as indicated by higher $\delta^{18} \mathrm{O}$ and $\mathrm{Sr} / \mathrm{Ca}$ values resulting from increased evaporation. The results of these case studies are compared to results of oxygen isotope analysis using more conventional methods and demonstrate the ability of the SHRIMP II to provide precise high spatial resolution in-situ oxygen isotope analyses of a variety of biogenic materials. This approach has major advantages over conventional methods. It can provide rapid, micro-scale isotopic analyses of sub-permil precision without the need for chemical preparation of the sample.
\end{abstract}

(c) 2012 Elsevier Ltd. All rights reserved.

\section{Introduction}

In situ isotope analysis using secondary ion mass spectrometry (SIMS) is now a well established geochemical method (Ireland, 1995; Valley et al., 1998). Over the last ten years, technique development has focussed particularly on high precision, high spatial resolution SIMS analysis of light stable isotopes $(\mathrm{C}, \mathrm{O}, \mathrm{N}, \mathrm{S})$. It is now possible to obtain accurate $\delta^{18} \mathrm{O}$ measurements $(0.3 \%$ standard deviation, SD) on spot sizes in the range $10-15 \mu \mathrm{m}$ and about $1 \%$ SD for spot sizes of 1-3 $\mu \mathrm{m}$ (Schuhmacher et al., 2004; Kita et al., 2009; Eiler et al., 2011). This allows, for example, the investigation of oxygen isotope variations in single foraminifera (Kozdon

\footnotetext{
* Corresponding author. Centre for Archaeological Science, School of Earth \& Environmental Sciences, University of Wollongong, Building 41, Northfields Avenue, Wollongong, NSW 2522, Australia.

E-mail address: maubert@uow.edu.au (M. Aubert).
}

et al., 2009), achieving daily resolutions in fish otoliths (Weidel et al., 2007) and sub-annual resolutions in speleothems (Treble et al., 2005, 2007). Here we report on the potential of in situ oxygen isotope analysis using an ion microprobe in palaeoecological and archaeological applications.

Oxygen isotope analysis of biogenic phosphates and carbonates has long been recognised as a powerful tool for palaeo-ecological and archaeological research. Biogenic materials such as corals (e.g. Cole et al., 2000), foraminifera (e.g. Wade and Kroon, 2002) and conodonts (Trotter et al., 2008) have been used as proxies to reconstruct changes in the oxygen isotope composition and temperature of sea water over geological timescales, providing information about global palaeo-climates. Bone or tooth phosphate from land mammals has been shown to reflect the oxygen isotopic composition of the ingested water (Land et al., 1980; Longinelli, 1984; Luz et al., 1984; Luz and Kolodny, 1985). This, in turn, is highly dependent on the ambient temperature or amount of 
rainfall, and a combination of other parameters such as distance from the coast and wind patterns (Gat, 1996). Thus, from the oxygen isotope composition of teeth, information about palaeoclimate and/or the degree of seasonality can be obtained (Fricke and O'Neil, 1996).

Traditionally, tooth enamel samples are micro-drilled in a sequence of grooves across the growth bands to extract spatially resolved phosphate and carbonate samples for isotope analysis by gas-source mass spectrometry. The spatial resolution achievable is limited by the need to obtain $5-10 \mathrm{mg}$ of material and to penetrate the entire thickness of the enamel. The drilled grooves have a wide range of diameters and lengths depending on the enamel thickness and tooth size. In the example of the steenbok tooth discussed below, the grooves were $1 \mathrm{~mm}$ diameter and extended $10 \mathrm{~mm}$ across the enamel surface. This procedure is adequate for the analysis of fast growing teeth such as from herbivores but cannot provide seasonal information from human teeth in which the annual enamel growth bands are much thinner and the enamel structure is more complex (Macho et al., 2003). The daily growth in human molars has been estimated to be about 4-6 $\mu \mathrm{m}$ (Dean and Shellis, 1998).

Similarly, otoliths have a demonstrated potential to yield palaeo-climate information. Their oxygen isotopic compositions record ambient conditions experienced by individual fishes throughout their life (e.g. Patterson et al., 1993; Campana, 1999). Otoliths are characterised by daily and annual micro-structural increments (Campana and Neilson, 1985) enabling the recovery of high-resolution isotope profiles, representing time-specific indices of environmental conditions (Wurster et al., 2005; Dufour and Gerdeaux, 2007). High-resolution sampling (from 20 to $200 \mu \mathrm{m}$ ) and high temporal resolution (sub-monthly) are achievable using a Micromill device (e.g. Patterson, 1999; Dufour et al., 2008), but this approach is very time consuming and the sampling can be complicated by the complex shape and small size of otoliths (Dufour et al., 2008; Wurster et al., 1999).

In situ infrared and ultra-violet laser ablation techniques have also been used to measured oxygen isotopes in bioapatite (Cerling and Sharp, 1996; Sharp and Cerling, 1996; Jones et al., 1999; Passey and Cerling, 2006; Podlesak et al., 2008). The spot sizes are usually on a spatial scale of $100-200 \mu \mathrm{m}$ and $100 \mu \mathrm{m}$ deep (for infrared laser; Passey and Cerling, 2006) and about $100 \mu \mathrm{m}$ and $50 \mu \mathrm{m}$ deep (for ultra-violet laser: Jones et al., 1999). However, the heat from the infrared laser can create damage halos that may be as large as $800 \mu \mathrm{m}$ around the ablation pit (Sharp and Cerling, 1996) and background $\mathrm{CO}_{2}$ contamination and surface- $-\mathrm{CO}_{2}$ interactions can be an issue (Passey and Cerling, 2006). Ablation of bioapatite by ultra-violet laser in $F_{2}$ gas does not result in damage halos around the ablation area but large amounts of contaminant fluorides derived from reactions of $F_{2}$ gas with organics within the sample have been observed. This effect can be reduced by coating the specimen with a thin layer of gold (Jones et al., 1999).

The Sensitive High Resolution Ion MicroProbe (SHRIMP) developed at the ANU Research School of Earth Sciences allows the high mass resolution, in-situ measurement of many isotopes using secondary-ion mass spectrometry on a spatial scale of $10-30 \mu \mathrm{m}$. Following significant advances on the original SHRIMP I design (Clement et al., 1977), it is now possible with SHRIMP II to make high precision analyses of light stable isotopes (Ickert et al., 2008), and a specialised stable isotope SHRIMP SI (Ireland et al., 2008) has been built.

Using SHRIMP II, oxygen isotopic compositions can be measured on polished sections of faunal material with spot sizes $\sim 25 \mu \mathrm{m}$ diameter and $2-3 \mu \mathrm{m}$ deep. This approach is superior to conventional methods as it is rapid, detects isotopic differences on a very fine spatial scale, and avoids chemical sample preparation. The best results are obtained when the sample is sectioned. In that case, the loss of material resulting from cutting the sample $(\sim 100 \mu \mathrm{m})$ is actually greater than the loss from the analyses themselves. After analysis, the two halves of the sample can be glued back together with little visible damage.

In this study, we explore the potential application of in situ $\delta^{18} \mathrm{O}$ measurements to a variety of archaeological samples, including fossil tooth enamel and fossil otolith aragonite. We demonstrate an ability to resolve oxygen isotopic differences of about $0.5 \%$ on a sampling scale of $25 \mu \mathrm{m}$. This allows a higher spatial resolution for analyses of herbivore teeth and human molars, and a less expensive and faster study for otoliths than conventional analyses, and enables the detection of small-scale, commonly quite large, intrasample differences in isotopic composition.

\section{Analytical procedures}

\subsection{Oxygen isotope analysis}

The sectioned samples for SHRIMP analysis were cast in epoxy resin (Struers Epofix) as $35 \mathrm{~mm}$ "Megamounts" and polished using 1200 grade $\mathrm{SiC}$ paper and $1 \mu \mathrm{m}$ diamond paste. Instrumental configuration and analytical procedures were similar to those detailed by Ickert et al. (2008). In brief, the RSES SHRIMP II was operated in multi-collector, negative ion mode. A $15 \mathrm{kV}, \sim 3 \mathrm{nACs}{ }^{+}$ primary ion beam was focused to a $25 \mu \mathrm{m}$ diameter spot on the Al-coated target, producing $200-250 \mathrm{pA}$ of secondary ${ }^{16} \mathrm{O}^{-} .{ }^{16} \mathrm{O}^{-}$ and ${ }^{18} \mathrm{O}^{-}$were measured simultaneously on Faraday cups using Keithley 642 electrometers. Target charging was neutralised using $\sim 350 \mathrm{eV}$ electrons from an oblique-incidence, focused electron gun. Analyses were corrected for a small amount of isotopically fractionated electron-induced secondary ion emission. Each analysis consisted of a pre-burn of about $3 \mathrm{~min}$ to allow the secondary ion isotopic composition to stabilise, followed by 10 or 14 (depending on the session) 10 -s estimates of the ${ }^{18} \mathrm{O} /{ }^{16} \mathrm{O}$ ratio. A standard (Durango apatite or NBS-19) was analysed first, then again after every five samples. Sample $\delta^{18} \mathrm{O}_{\text {apatite }}$ and $\delta^{18} \mathrm{O}_{\text {carbonate }}$ values were determined by difference relative to the mean ${ }^{18} \mathrm{O} /{ }^{16} \mathrm{O}$ measured on the standard following normalisation for any longterm drift in its measured composition. The $\delta^{18} \mathrm{O}$ of Durango apatite relative to VSMOW was taken as $9.4 \%$, based on a determination of the composition $(9.4 \pm 0.3 \%, 2 \sigma)$ by GIRMS at the Université Claude Bernard Lyon, France (Lécuyer et al., 2003). The precision of each determination, usually $0.1-0.2 \%$, was calculated as the standard error of the mean of the 10 to 14 estimates of ${ }^{18} \mathrm{O} /{ }^{16} \mathrm{O}$ for that spot analysis. The standard deviation of replicate analyses of each reference material was about $0.3 \%$.

\subsection{Elemental analysis}

Fish otolith elemental strontium ( $\mathrm{Sr}$ ) and calcium (Ca) analyses were carried out using a custom-built laser ablation sampling system (ANU HelEx) interfaced between an ArF Excimer laser (193 nm; Lambda Physik Compex 110) and a Varian-820 quadrupole inductively coupled plasma mass-spectrometer (ICP-MS). The ANU system and its capabilities have been described in detail by Eggins et al. (1998a, b). In brief, it employs a single long-working distance lens to project and demagnify (by a factor of 30) the image of a laser-illuminated aperture onto the sample surface, which enables a range of geometries to be ablated within bounding dimensions of between about 5 and $400 \mu \mathrm{m}$. In this study, a spot size of $100 \mu \mathrm{m}$ and laser pulse rate of $10 \mathrm{~Hz}$ were employed with a fluence of $5 \mathrm{~J} / \mathrm{cm}^{2}$ at a stage speed of $10 \mu \mathrm{m}$ per second resulting in the removal of a uniformly thick layer $(\sim 20 \mu \mathrm{m})$ from the targeted 
sample site $(\sim 0.1-1.2 \mu \mathrm{m}$ per laser pulse). The laser ablation cell developed in-house produces very fast response times, which permits high depth resolution analysis. Data reduction followed established laser ablation ICP-MS protocols (after Longerich et al., 1996).

\section{Applications}

\subsection{Oxygen isotope analysis of tooth enamel}

Oxygen isotope ratios in mammals' drinking water, as recorded in their tooth enamel, serve as a proxy for palaeo-precipitation. This in turn is a proxy for palaeo-temperature because of the progressive raining out of vapour masses as they move towards regions with lower temperatures, i.e. higher latitudes and altitudes (Faure and Mensing, 2005) and the temperature dependant fractionation of oxygen during its incorporation into animal tissues (Grossman and $\mathrm{Ku}, 1986$ ). Once formed, enamel is not remodelled, so the isotopic values along a tooth represent a time sequence of changes in isotopic composition during its growth (Fearne et al., 1994). The oxygen isotopic composition of a growing mammal tooth can vary with the changes of season and so provide a powerful seasonal marker to which to relate other compositional changes in the teeth. This approach has been applied to a suite of African herbivores (Kohn et al., 1996), beavers (Stuart-Williams and Schwarz, 1997), fossil bison (Fricke and O'Neil, 1996), modern ungulates (Balasse et al., 2003; Sharp and Cerling, 1998; Wiedemann et al., 1999) and wombats (Fraser et al., 2008).

Enamel formation involves two distinct stages, secretion and maturation. During the secretory stage of human tooth enamel, only about $14 \mathrm{wt} \%$ of the mineral content of mature enamel is deposited (Smith, 1998). This is followed by the maturation stage, which is characterised by the degradation of the organic matrix and secondary mineralisation. During this stage, about $86 \mathrm{wt} \%$ of the mineral content of mature enamel is deposited (Smith, 1998). This secondary process does not mineralise the whole enamel thickness equally, but proceeds in successive fronts cutting across the front of matrix secretion, which in turn is oblique to the dentine-enamel junction (Suga, 1982, 1989). Consequently, intra-tooth enamel samples for elemental and isotopic analysis can have a "dampened" signal, being shifted in time or modified in degree (Smith and Tafforeau, 2008). Taxa with short maturation times are therefore the best recorders of seasonality.

Tooth enamel contains $<1$ wt\% carbonate, 96 wt\% calcium phosphate, $\sim 3 \mathrm{wt} \%$ water, and $\sim 1 \mathrm{wt} \%$ organic matter (Hilson, 1986; Driessens and Verbeeck, 1990). The enamel phosphate and carbonate oxygen are precipitated in equilibrium with each other. The corresponding carbonate oxygen values are, at equilibrium, 8.6-9.1\% higher than the phosphate oxygen (Iacumin et al., 1996). Since the study of Iacumin et al. (1996), there have been further studies that (a) refine the value and (b) suggest that there may be variation within a tooth in the offset (cf. Pellegrini et al., 2011). The in situ SHRIMP analyses are dominated by the oxygen composition of the phosphate phase, but it is the carbonate phase that is normally analysed conventionally.

Fossil tooth enamel can be prone to diagenetic contamination and alteration changing the oxygen isotopic composition. Precipitation of secondary calcite in the pore space of the material can affect the bulk isotope values (Kohn et al., 1999). Additionally, inorganic and organic-induced alteration can affect the oxygen isotope compositions of carbonate $\left(\delta^{18} \mathrm{O}_{\mathrm{c}}\right)$ and phosphate $\left(\delta^{18} \mathrm{O}_{\mathrm{p}}\right)$ in bioapatite. Using sequential $\delta^{18} \mathrm{O}_{\mathrm{c}}$ and $\delta^{18} \mathrm{O}_{\mathrm{p}}$ analysis on fossil hypsodont enamel and dentine, Zazzo et al. (2004) have estimated that diagenesis can alter $\delta^{18} \mathrm{O}_{\mathrm{p}}$ by as much as $3 \%$.

\subsubsection{Comparison between SHRIMP and conventional analyses}

A fossil steenbok tooth from South Africa was analysed with the SHRIMP II and the results compared with those previously obtained from a micro-milled profile from the same sample analysed by conventional mass spectrometry (Balasse et al., 2002). Steenbok teeth are well suited for seasonality studies because their enamel matures over a short period of time ( $\leq 1$ month, Kohn, 2004, Table 1).

The conventional analyses were carried out on the carbonate fraction, resulting in a $\sim 9 \%$ offset compared to our in situ analyses, which were primarily of calcium phosphate. On average, we were able to reproduce the variation in oxygen isotope ratios observed by Balasse et al. (2002) (Fig. 1B). However, there is a $1-2 \%$ discrepancy with some of the micro-drilled samples. This could be explained by the scale of the micro-drilling, which averages the isotopic composition of a sample volume about seven orders of magnitude larger than that sampled by each SHRIMP analysis. It could also reflect a delay between the accumulation of carbonate and phosphate ions (Pellegrini et al., 2011). Additionally, fossil samples are prone to diagenesis affecting the carbonate and/or the phosphate fraction, resulting in an isotopic offset between the two fractions. The higher spatial resolution of the SHRIMP shows a more complex and detailed microstructure in which intra-tooth isotopic excursions are clearly visible (Fig. 1A). Some of the intra-sample variability might be explained by differences in the depth into the enamel sampled by the SHRIMP. Zazzo et al. (2005) have shown (in a cattle tooth) that, at a given point in the tooth crown, the isotopic composition changes as a function of depth in the enamel layer. Our SHRIMP samples were not all taken at the same distance from the enamel surface. A correlation between distance from the enamel surface and the $\delta^{18} \mathrm{O}$ is observable in the interval between 4 and $5 \mathrm{~mm}$, and possibly after $9 \mathrm{~mm}$ (Fig. 1A).

\subsubsection{Teeth from the archaeological site at Payre, France}

Teeth from three herbivores (two deer and a bison) and a Neanderthal from the Palaeolithic site of Payre were analysed using the SHRIMP II. Numerous faunal teeth from this site had previously been analysed by a range of isotopic techniques: U-series, Sr, O and C (e.g. Aubert et al., 2007; Kelly et al., 2007; Grün et al., 2008; Bocherens and Rousseau, 2008).

The archaeological site of Payre in southern France, adjacent to the Rhône River, has been the subject of archaeological investigation starting with Combier (1967) and has since been regularly excavated (Moncel, 2003). The site contains a rich faunal, human fossil and artefact assemblage (Debard, 1988; Moncel, 2004, 2003; Moncel et al., 2002, 2005; Moncel and Condemi, 1996, 1997) over an occupation history of approximately 300,000 years (Valladas et al., 2008). The $5 \mathrm{~m}$ thick stratigraphic sequence is divided into 5 main units, named from the base to the top: G, F, E, D-C and B-A, each of which includes several sub-levels. The sequence lies above a $25 \mathrm{~cm}$-thick stratified stalagmitic floor located on the western side of the cave and divided into seven sub-levels ( $\mathrm{H} 1-\mathrm{H} 7$, from the top to the bottom).

Dating of samples from Payre by a range of methods has recently been summarised by Valladas et al. (2008). Levels D and E yielded ESR/U-series age estimates on faunal materials, as well as thermoluminescence results on burnt flint, in the vicinity of $150 \mathrm{ka}$. Ages from layers $F$ and $G$ were in the range 200-300 ka, with no distinction between the two layers. The underlying stalagmitic floor yielded TIMS U-series ages in the range 230-290 ka.

3.1.2.1. Payre deer and bison. We analysed a Neanderthal tooth from Level $G$ and herbivore teeth from levels $G$ and F. Deer tooth enamel grows about $50 \mathrm{~mm}$ per year (Fricke et al., 1998) and bison enamel about 40-50 mm (Fricke and O'Neil, 1996; Feranec and 

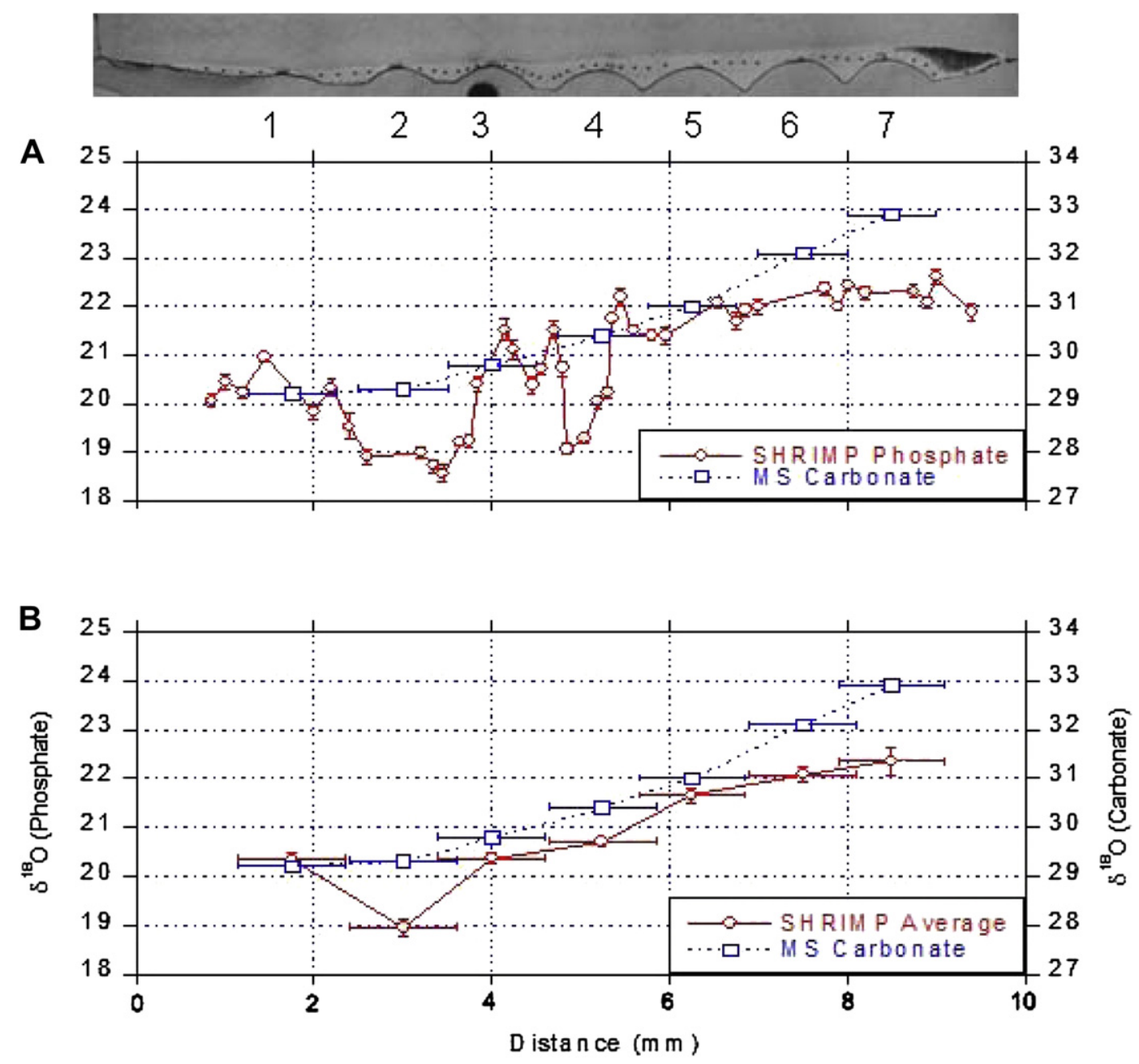

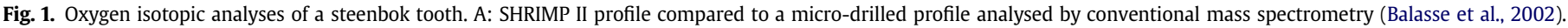
B: Average SHRIMP II profile compared to a micro-drilled profile analysed by conventional mass spectrometry (Balasse et al., 2002).

MacFadden, 2000). The enamel maturation time for both species is approximately 6 months (Kohn, 2004, Table 1).

Animal teeth from levels D (7 samples), F (4 samples) and G (6 samples) were also analysed conventionally for bulk oxygen and carbon isotopes (Bocherens and Rousseau, 2008). Carbonate oxygen enamel samples from level D and F averaged about $27 \%$ $\delta^{18} \mathrm{O}$, while samples from level $\mathrm{G}$ yielded lighter values of about $22 \%$ (Bocherens and Rousseau, 2008). On average, our SHRIMP phosphate $\delta^{18} \mathrm{O}_{\mathrm{p}}$ results replicate this trend. Allowing for a $9 \%$ offset between carbonate and phosphate (Iacumin et al., 1996), the measured values of about 18 and 13\%, respectively (Fig. 2), replicate the conventional measurements exactly.

The SHRIMP analyses show a general trend towards lighter oxygen along the growth axis of the deer teeth from Levels F (Fig. 2). Additionally, a weak quasi-sinusoidal isotopic cycle can be observed in the tooth from Level G. These are probably related to seasonal variations. The two teeth represent about 3 months of growth and have an internal oxygen variation of 6 and $8 \%$ respectively, similar to modern seasonal shifts in rainwater oxygen isotopes for continental Europe (IAEA, 1992).

The bison tooth from Level $\mathrm{F}$ has a more limited compositional range, with the exception of between 3 and $6 \mathrm{~mm}$, where the oxygen isotopic ratio increases significantly (Fig. 2). There is a second section of heavy oxygen between 8 and $11 \mathrm{~mm}$. Assuming a yearly enamel growth length of $40-50 \mathrm{~mm}$, the whole tooth represents 3.5-4.5 months of growth, and these two domains only 20-30 days each. It is unlikely that they are related to seasonal variations; they could instead be related to diagenesis (cracks are visible in the enamel along the growth axis). They might also be related to local effects. The site is located at an intersection between high plateau and humid valleys (Moncel et al., 2002) and these contrasting environments could have a significant impact on oxygen fractionation.

Based on their bulk enamel oxygen isotope analyses, Bocherens and Rousseau (2008) concluded that Level F represents a warmer and dryer environment then Level G. They also stressed that the differences between Levels $F$ and $G$ did not necessarily imply climatic changes, but might correspond to changes in the feeding habits of large herbivores or in human hunting territories. Our in situ data show a more complex and detailed story where intra-tooth variations, possibly the result of seasonal effects, can be significantly larger that the differences in bulk values. For example, the deer from Level $\mathrm{G}$ has an $8 \%$ range in $\delta^{18} \mathrm{O}_{\mathrm{p}}$, almost twice the difference in bulk values measured by Bocherens and Rousseau (2008).

3.1.2.2. Payre Neanderthal. We analysed an adult Neanderthal tooth from level G, not to be confused with the juvenile tooth from level D previously analysed for U-series (Grün et al., 2008) and Sr isotopes (Aubert et al., 2007). The dentition of a Neanderthal differs from that of deer and bison. The total enamel formation times in Neanderthal 


\section{Herbivores, Payre}

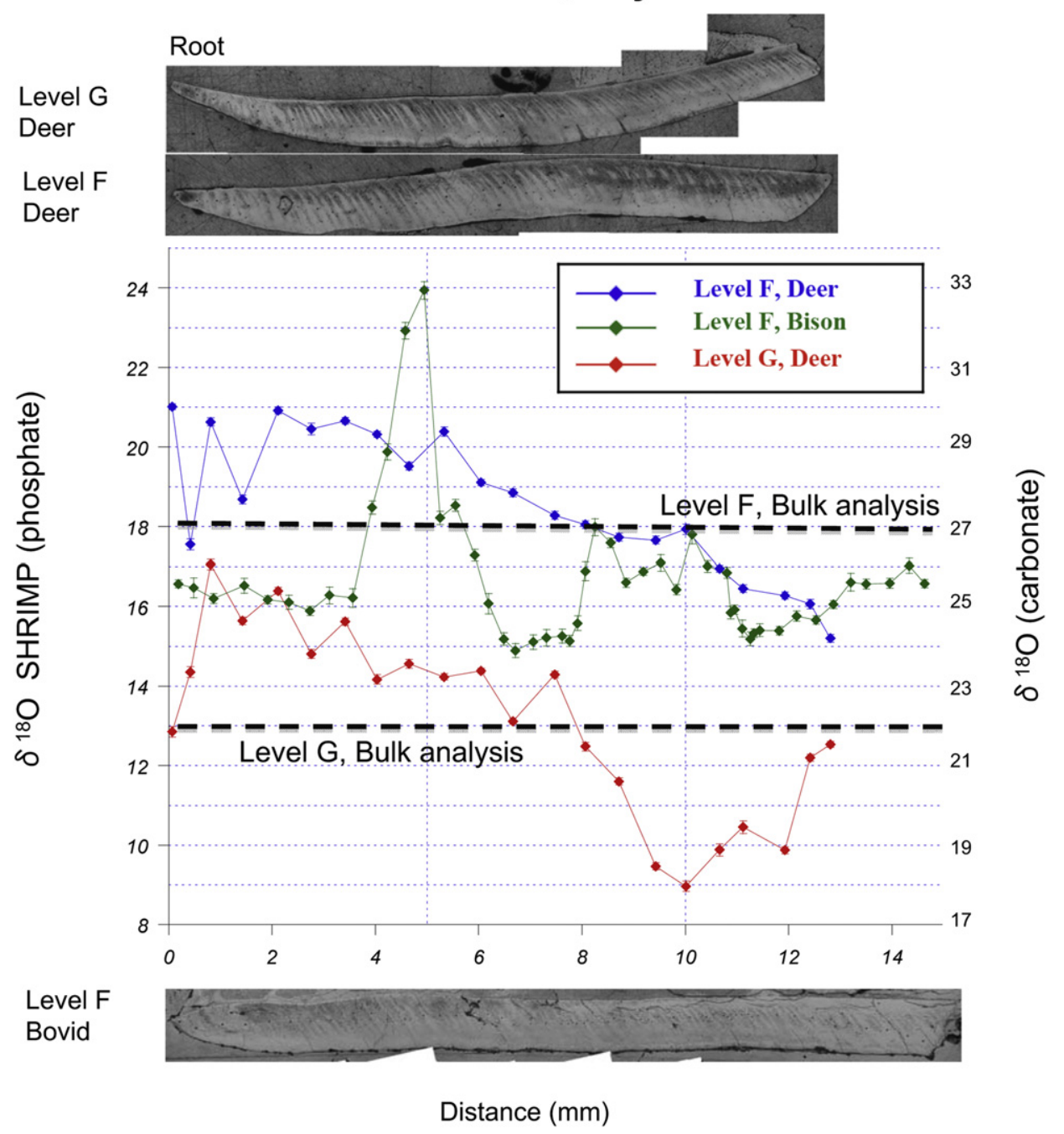

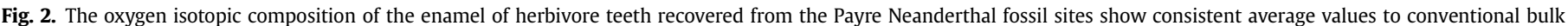
values. There also appear to be domains that could be related to seasonal variations.

molars were closely similar to those of modern humans, about 1000 days (Macchiarelli et al., 2006). Approximately two-thirds of this time was devoted to the maturation stage (Smith, 1998).

When compared to the deer from level G, the Neanderthal tooth enamel shows a much smaller range of isotopic compositions (about $1 \%$ ), averaging about $13 \% \delta^{18} \mathrm{O}_{\mathrm{p}}$ (Fig. 3). This is consistent with the average SHRIMP and conventional bulk values for the herbivores from the same level (Fig. 3). The human enamel maturation stage is longer (about two years) than for deer and bison. This could result in an averaging of the isotopic composition and explain why the Neanderthal tooth does not show clear signs of seasonal variations. An alternative interpretation is that the Neanderthal had a much more restricted feeding range and/or more uniform sources of drinking water as the teeth were growing.

There is a domain of lighter oxygen isotopes between 4 and $5 \mathrm{~mm}$ (Fig. 3A). This domain is located between two cracks in the enamel and the oxygen isotopes might be affected by the formation of secondary carbonates. An additional domain of heavier oxygen isotopes represented by only 2 analyses (Fig. 2B) is also noticeable. This could be attributed to the different mineralisation stage where the innermost layer is heavily mineralised early during the stage of matrix secretion (Balasse, 2003).

\subsection{Oxygen isotope analysis of fish otoliths}

Stable isotope studies of fish otoliths have become commonplace for both biological research (Campana, 1999) and palaeoenvironmental reconstructions (Patterson et al., 1993), with various workers focussing on the $\mathrm{C}, \mathrm{N}, \mathrm{O}$ or $\mathrm{Sr}$ systems. Equally common is the application of elemental concentration ratios such as $\mathrm{Sr} / \mathrm{Ca}$ or $\mathrm{Ba} / \mathrm{Ca}$ (Elsdon and Gillanders, 2002). Reviews of the literature about the analysis of otolith chemical compositions have been published by Campana (1999), Thresher (1999) and Elsdon et al. (2008).

Fish otoliths are aragonitic precipitates with about 3\% organic matrix (Campana, 1999) that are part of fish ears. The otolith crystallises out of the endolymph fluid, the growth occurring in daily, seasonal and annual increments (Campana and Neilson, 1985). The rate of accretion may exceed $1 \mathrm{~mm} / \mathrm{a}$ in some species, resulting in visible layers from which an age of the fish can be calculated (Campana, 1999). Otolith aragonite has been demonstrated to precipitate in or very near to isotopic equilibrium with the $\delta^{18} \mathrm{O}$ of both environmental fresh (Patterson et al., 1993) and marine water (Thorrold et al., 1997), with a relationship similar to that defined by Grossman and Ku (1986) for biological aragonite 

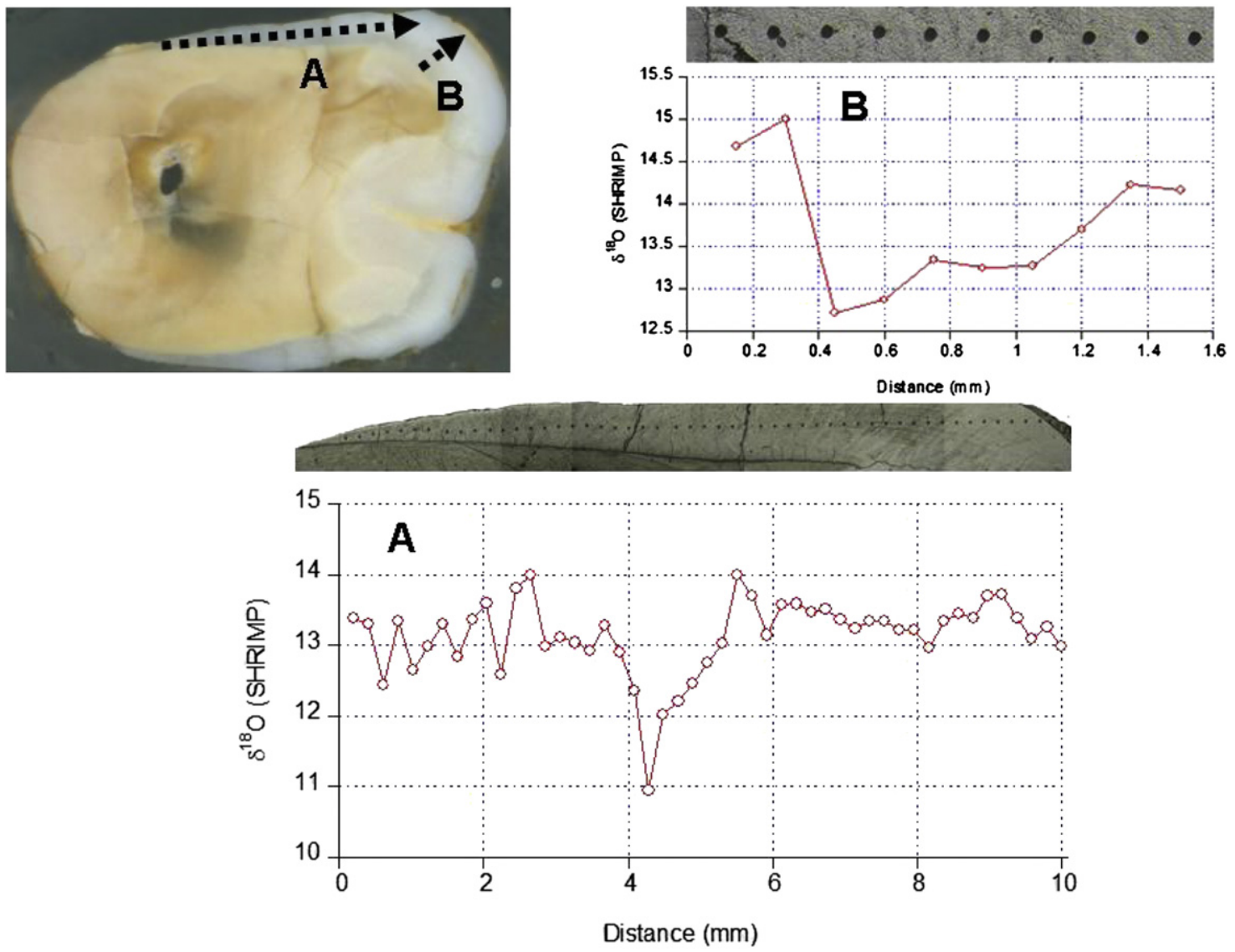

Fig. 3. The Neanderthal tooth from Payre Level G did not reveal any expected seasonal variations. Whether this is due to diagenetic effects requires further investigation.

precipitated by other species. This suggests that otoliths should faithfully record palaeo-environmental conditions such as temperature and salinity (Campana, 1999). Additionally, the acellular and metabolically inert nature of otoliths means that once material is deposited it is retained throughout life and not subject to resorption during periods of stress.

The relationship between the $\mathrm{Sr} / \mathrm{Ca}$ ratio in otoliths and the ambient water salinity has been examined for many species (e.g. Secor et al., 1995; Secor et al., 1998; Kawakami et al., 1998). It appears that the response of otolith $\mathrm{Sr} / \mathrm{Ca}$ ratios to salinity differs between species (Lin et al., 2007) and that water chemistry (including salinity), diet, temperature (Elsdon and Gillanders, 2002), reproductive state (Kalish, 1991), stress (Kalish, 1992) and age (Fowler et al., 1995) all have the potential to influence otolith elemental compositions (Campana, 1999). The main determinant of otolith composition, however, is probably salinity (Zimmerman, 2005).

Otoliths are thought to be relatively resistant to post depositional alteration, some having retained their original compositions from periods as long ago as the Pliocene (Dufour et al., 2000), the Oligocene/Miocene boundary (Ivany et al., 2000) and the Cretaceous (Carpenter et al., 2003). If otoliths are burnt, however, for example in a camp fire, both isotopic and elemental compositions can change (Andrus and Crowe, 2002).

Various instrumental approaches have been applied to the analysis of otoliths. Bulk analysis is widely utilised (e.g. Ashford and Jones, 2007), as is micro-drilling followed by conventional mass spectrometric analysis (e.g. Dufour et al., 2008; Huxham et al., 2007; Shephard et al., 2007; Surge and Walker, 2005). Hanson et al. (2010) compared the use of mechanical micro-milling and continuous flow isotope ratio mass spectrometry (CF-IRMS) methods with secondary ion mass spectrometry (SIMS) to obtain oxygen isotope profiles from otoliths of wild Atlantic salmon (Salmo salar). Laser ablation multi-collector ICP-MS (LA-ICP-MS) sampling was used by Outridge et al. (2002), and Weber et al. (2005) measured $\mathrm{Sr}$ isotopic compositions by ion microprobe.

\subsubsection{Comparison between SHRIMP and conventional analyses}

3.2.1.1. Archaeological fish otolith from Northern Peru. The SHRIMP technique for otolith analysis was tested on a well-preserved Micropogonias altipinnis otolith (QC-D) from a Paíjan site of the "Pampa de los Fóssiles" group, near of the village of Paíjan on the northern margin of the Chicama Valley, Northern Peru (Chauchat, 1988). This group of sites, radiocarbon dated at between 11,000 and $8500 \mathrm{BP}$, is $15 \mathrm{~km}$ from the present shoreline. Because sea level at the time was much lower than it is today, they were originally at least $10 \mathrm{~km}$ further inland. The hunter-fisher-gatherers from Paíjan are the first known humans to inhabit the desert coasts of Peru and are characterised by distinctive lithic tools (Chauchat, 1988; Chauchat et al., 1992, 2004).

Proxies for reconstructing ancient climate and environmental conditions along the desert coast of Peru are rare. Faunal remains from archaeological sites provide an opportunity to gain insight into the environmental conditions experienced by Paíjan humans. The ichtyofaunal material (bones and otoliths) comes from a typical tropical fauna associated with coastal habitats such as embayments or lagoons (Béarez et al. 2011). At present the site is characterised by temperate oceanic and semi-arid continental conditions. The presence of a shallow fresh water back barrier lagoon would create an environment of increased water temperature and could explain the tropical fauna. Oxygen and carbon analyses of the QC-D otolith 
by conventional isotopic mass ratio spectrometry (c-IRMS) at the Service de Spectrométrie de Masse Isotopique of the Muséum National d'Histoire Naturelle (Paris, France) are consistent with a local fresh water habitat and more humid conditions (Béarez et al., 2011).

The conventional analyses of the otolith were conducted using a Delta Advantage mass-spectrometer coupled to a Kiel IV (Thermo). Micro-samples were drilled along 43-100 $\mu \mathrm{m}$ wide tracks parallel to the annual growth banding (Wurster et al., 1999) using a New Wave Micromill. Each track yielded about $120 \mu \mathrm{g}$ of sample, $30 \mu \mathrm{g}$ aliquots of which were analysed for $\delta^{18} \mathrm{O}$ (and $\delta^{13} \mathrm{C}$ ). The analytical precision was $0.04 \%$ for $\delta^{18} \mathrm{O}$, assessed from repeated analyses of NBS-19 $(n=26)$. Sample preparation took one and a half days for micro-sampling and another day and a half for 42 isotope analyses. In comparison, the effective sample preparation time for SHRIMP II was about $2 \mathrm{~h}$, and 65 oxygen analyses were carried out in one day.

The results of the c-IRMS and SHRIMP II analyses are illustrated in Fig. 4. Isotope profiles for both techniques were obtained by sampling the same frontal thin section from the core to border of the inner face of the otolith. Although short, this axis was preferred because of the convoluted growth sequence in other directions, which would make it difficult to micro-sample and to match age and point data collection. Assigning an age to QC-D is difficult because no study has validated the timing and periodicity of growth mark deposition in M. altipinnis otoliths, but from a growth ring count, we estimate that the fish died when about 6 years old.

Both the c-IRMS and SHRIMP II isotope profiles exhibit large ontogenetic variations and smaller cyclic variations in $\delta^{18} \mathrm{O}$ values (Fig. 4). Only small differences are observed in the sequence of variations. These slight differences might be due to the difficulty in perfectly aligning the SHRIMP II sampling points with the microdrilled tracks (the section needed to be repolished between Micromill micro-sampling and SHRIMP II analysis). The number of $\delta^{18} \mathrm{O}$ cyclic variations is in accordance with the estimated age of QC$\mathrm{D}$, suggesting that they are related to seasonal changes in ambient water temperature.

The SHRIMP II profile records one large negative excursion $(\sim 5 \%)$ during the first year of life and two smaller negative excursions $(\sim 2 \%)$ during the third and fourth years of life. The c-IRMS profile shows negative excursions at the same locations, but they are smaller $(\sim 3 \%$ and $\sim 1.5 \%$ for the large and two small excursions, respectively). These variations in $\delta^{18} \mathrm{O}$ values identify short duration (less than one year) changes in the life history of the fish. Fresh and brackish water usually have lower $\delta^{18} \mathrm{O}$ values than sea water, so the falls in otolith $\delta^{18} \mathrm{O}$ possibly record the fish migrating briefly from the open ocean into an estuary or river. Otolith $\delta^{18} \mathrm{O}$ also changes inversely with water temperature, so a short-lived increase in sea water temperature, such as during a brief El Niño event, might also explain the drops in $\delta^{18} \mathrm{O}$ value.

While the major features of both profiles are the same, the $\delta^{18} \mathrm{O}$ values are slightly different. The mean value for the SHRIMP II profile is $0.8 \%$ o lower than that of the c-IRMS profile (Fig. 4), possibly because SHRIMP II fractionates the oxygen from otolith aragonite and NBS calcite by slightly different amounts. This could be accessed by measuring an aragonite internal standard. The fact that both c-IRMS and SHRIMP II analyses show the same intraotolith variations in $\delta^{18} \mathrm{O}$ suggests that both methods are suitable for reconstructing the complex life history of a fish. The smaller magnitude of the variations measured conventionally is probably related to slight mixing of material from different growth bands during micro-milling, thereby decreasing the temporal resolution. Further, the level of detail in the SHRIMP II record is higher in some portions of the profile, especially at the beginning where the fish is young and the growth banding is thinnest, compromising the temporal resolution achievable by micro-drilling. On the other hand, the analytical precision achieved by micro-drilling and c-IRMS is about 5 times better than that achieved by SHRIMP II.

\subsubsection{Lake Mungo, Australia}

Lake Mungo lies within the Willandra Lakes system, a series of palaeo-lakes formed along Willandra Creek, a former tributary of the Lachlan River in western New South Wales. These lakes periodically filled and dried out during the last 50,000 years, leaving a comprehensive palaeo-climate record preserved in lunette sediments (Bowler, 1998; Bowler and Price, 1998).

Lake Mungo is perhaps best known as the location of some of the oldest human skeletal material found in Australia (Bowler et al. 1970; Bowler and Thorne, 1976), the dating of which has sparked robust scientific debate (Bowler and Magee, 2000; Bowler et al., 2003; Grün et al., 2000; Olley et al., 2006; Thorne et al., 1999).

The fish species most commonly represented by otoliths in the palaeo-lake system in the Willandra Lakes World Heritage Area is the golden perch Maquaria ambigua (Balme, 1983; Douglas et al.,

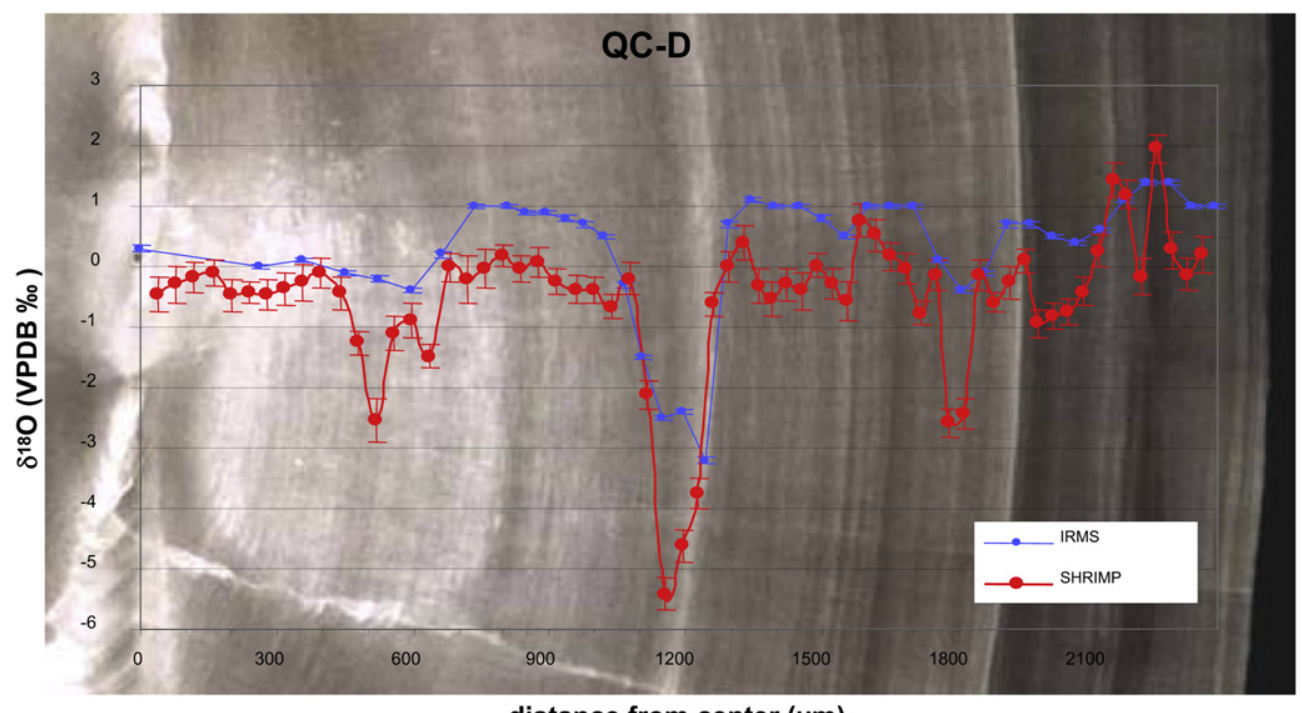

distance from center $(\mu \mathrm{m})$

Fig. 4. QC-D otolith $\delta^{18} \mathrm{O}$ results for SHRIMP II (data points with error bars) and conventional mass spectrometry. 
1994). Golden perch live a solitary life in warm, turbid, slow flowing waters where there is cover from debris (Allen et al., 2002). Outside the breeding season they typically have a home range of $\sim 100 \mathrm{~m}$, but they undertake large scale spawning migrations up to a recorded distance of $2000 \mathrm{~km}$ (Allen et al., 2002). Sexual maturity is reached by age 2 and 4 years for males and females, respectively (Mallen-Cooper and Stuart, 2003). Their reproductive cycle is largely synchronized to a rise in water level, so they usually spawn between November and February, after heavy summer rains (Allen et al. 1992).

Otoliths in M. ambigua continue to grow and deposit distinct, well spaced annual rings even after body growth of the fish has essentially ceased (Anderson et al., 1992). This allows high spatial/ temporal resolution measurement of stable isotope variation for the entire period of the fish's life. Although different fish species have different elemental uptake mechanisms, it has been demonstrated that water chemistry plays an important role in determining the otolith compositions in M. ambigua (Munro et al., 2008). The results of SHRIMP II and LA-ICP-MS analyses one such otolith are illustrated in Fig. 5.

Otolith BMLM 007 shows significant changes in $\delta^{18} \mathrm{O}$ at three locations. From birth to an age of 1.5 years, $\delta^{18} \mathrm{O}$ gradually decreases
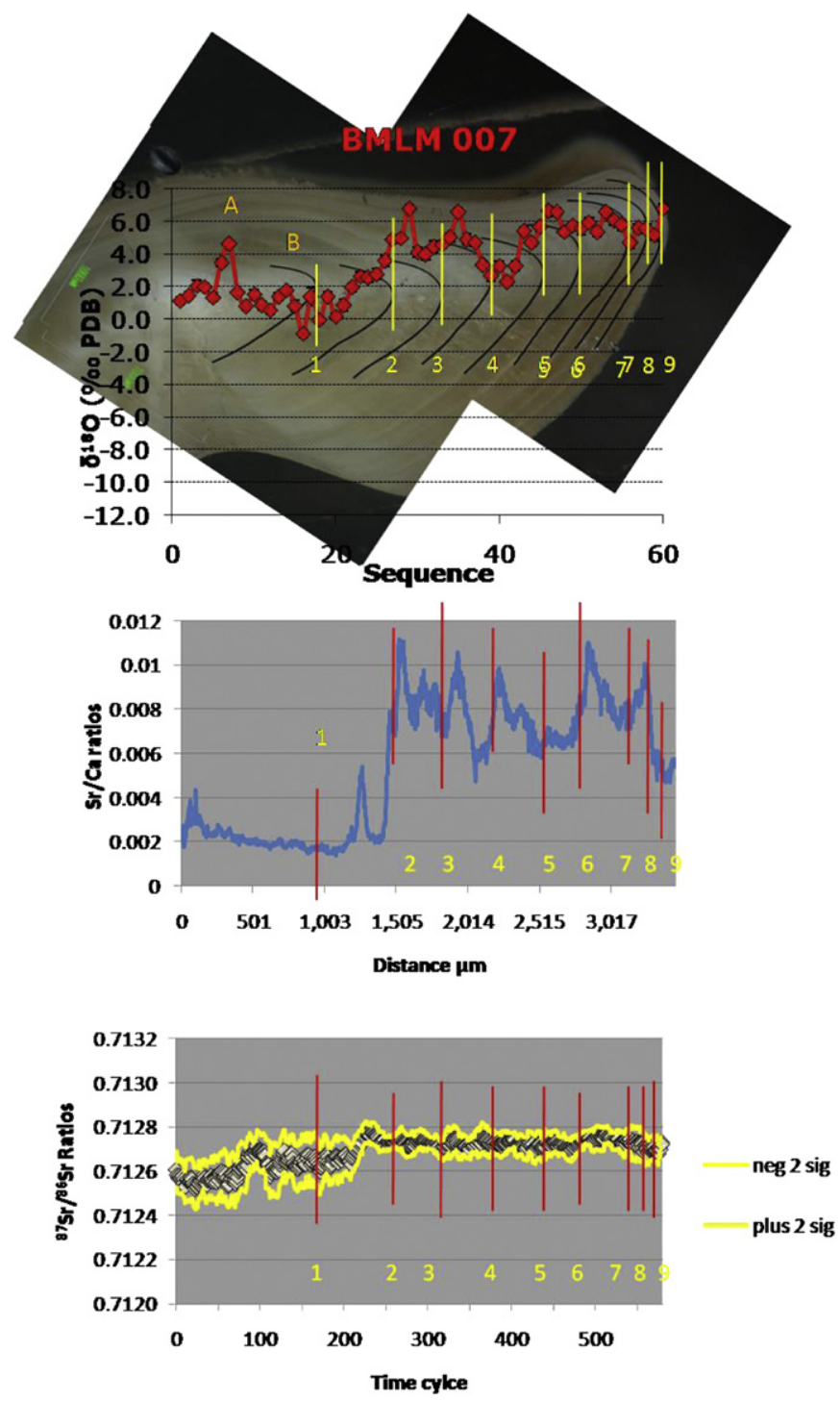

Fig. 5. $\delta^{18} \mathrm{O}, \mathrm{Sr} / \mathrm{Ca}$ and ${ }^{87} \mathrm{Sr} /{ }^{86} \mathrm{Sr}$ results for a Lake Mungo Golden Perch otolith. from $1.0 \%$ to $0.0 \%$, with two short-term excursions (A and B in Fig. 5). Each excursion is about 3\% and trend in opposite directions. The second phase begins at 1.5 years and lasts until 4.5 years. During this period, $\delta^{18} \mathrm{O}$ starts and finishes at $2.0 \%$, but rises to a maximum of $6.8 \%$ on two occasions, settling to about $4 \%$ in between. The third phase commences at age 4.5 years and lasts until death at about 9 years. It is characterised by a second period of isotopic stability, at $5.7 \%$. Seasonal variation is likely to be masked by annual averages in the later period of life due to the decreasing thickness of the annual bands. Variations in the $\delta^{18} \mathrm{O}$ of the magnitude observed in the otolith are similar to annual variations of $5 \%$ observed in $\delta^{18} \mathrm{O}$ values for modern Darling River waters at nearby Menindee (Gibson et al., 2008).

Two phases are evident in the $\mathrm{Sr} / \mathrm{Ca}$ ratios. The first phase, in common with the oxygen isotopes, displays a declining value from 0.003 to 0.002 . It is characterised by two short-term spikes, the first early in life, when the value rises to 0.004 , and the second just before age 2 , when it rises to 0.005 . The second phase is a rapid rise in $\mathrm{Sr} / \mathrm{Ca}$ from 0.002 to 0.0108. Large biannual fluctuations in $\mathrm{Sr} / \mathrm{Ca}$ characterise the remainder of the profile.

The simultaneous falls in relatively low $\delta^{18} \mathrm{O}$ and $\mathrm{Sr} / \mathrm{Ca}$ values during first 1.5 years of life indicate a shift to warmer waters with higher salinities. The significant rise in $\mathrm{Sr} / \mathrm{Ca}$ after that age possibly records migration, providing support to the hypothesis that this may occur upon sexual maturation. Biannual compositional changes are seen from age 2 onwards in both the $\delta^{18} \mathrm{O}$ and $\mathrm{Sr} / \mathrm{Ca}$ values, possibly recording seasonality and flood events, respectively.

A migration event at about 1.5 years is supported by multicollector LA-ICP-MS ${ }^{87} \mathrm{Sr} /{ }^{86} \mathrm{Sr}$ analyses which indicate a rise from between 0.7126 and 0.7127 before 1.5 years, to 0.7128 afterwards (Fig. 5C). Sr isotope analyses of fish otoliths from the Willandra Lakes area have been reported in detail by Boljkovac (2009).

The fish probably lived the first 1.5 years of its life in the same environment. At the age of 1.5 years, on sexual maturation, it moved to the lake where the water composition was determined by evaporation and salinity. The $\mathrm{Sr} / \mathrm{Ca}$ ratios and oxygen isotopic compositions change in concert, confirming that the salinity of the lake water increased as the water was evaporating. Additionally, the sample showed clear seasonal variations, but also a general trend to heavier oxygen isotopes with time, a possible indication that the heavy isotopes were enriched because of increased evaporation.

The analysed otolith was collected from a surface accumulation of several hundred otoliths at the northernmost extent of the Lake Mungo lunette. Their age has been estimated as 20,181 \pm 225 cal yr BP [20,406-19,956 cal yr BP] with IntCal 04. This age corresponds to the peak of deflation during the lake dry phase that caused the formation of the Zanci pelletal clay dune (Bowler, 1998), confirming that this was a period of low lake level. Deposition of the otoliths was probably cultural rather than via physiographic processes-the lake was at its driest at this time (and hence probably not full to this point), the otolith was contained in an aeolian unit, and several hundred otoliths were accumulated in the one location. This supports the hypothesis of Bowler (1998) that exploitation of fish in the region began as a result of the drying of the lake, although the analysis of more otoliths is required to test this contention.

\section{Conclusions and perspectives}

The examples discussed here demonstrate the potential of SIMS in general, and SHRIMP II in particular, to provide precise, accurate, in situ analyses of the oxygen isotopic compositions of biogenic materials with a spatial resolution of a few microns. Each material presents its own challenges, however, and major differences in the design of different SIMS instruments (SHRIMP II, SHRIMP SI, Cameca 3-6f series, Cameca NanoSIMS, Cameca 1270/1280) means 
that the precision and accuracy achieved with each instrument will not be the same. Further, the volume sampled for a SIMS analysis is several orders of magnitude smaller than even the smallest sample micro-drilled for c-IRMS, so good c-IRMS analyses will always be the more precise. The disadvantages of lower precision are offset, however, by the ability of the SIMS technique to resolve isotopic heterogeneity on a much smaller scale.

The close comparison between SIMS and c-IRMS analyses for the present study has emphasised several factors that must be considered in SIMS work on biogenic material. Analyses of the steenbok tooth showed the importance of being aware of potential isotopic differences between different components of the growing tooth. The same will apply to any biogenic mineralisation formed with a layered structure. Analyses of the Neanderthal tooth showed unexpected uniformity which, although enhancing confidence in the analytical technique, has several possible explanations that oxygen analysis alone cannot resolve. Analyses of the Peruvian fish otolith provided the most stringent test of the SHRIMP technique, compared as they were with exceptionally high spatial resolution c-IRMS data. Although both techniques showed the same features in the analysed profile (the SHRIMP detecting larger isotopic excursions in finer detail), the comparison revealed a systematic difference between the compositions measured by the two techniques. The most likely explanation is that there is a small, previously unknown, difference in SHRIMP instrumentally induced oxygen isotope fractionation between the NBS calcite standard and otolith aragonite. Analyses of the Pleistocene fish otoliths from Lake Mungo revealed another issue, this time related to data interpretation. Oxygen isotopic compositions in otoliths are determined by a range of factors, the most important being those that affect the composition of the water the fish was living in (water source, salinity and temperature). Oxygen isotopic analyses alone cannot resolve these, but when combined with other data, for example measurements of $\mathrm{Sr} / \mathrm{Ca}$ and ${ }^{87} \mathrm{Sr} /{ }^{86} \mathrm{Sr}$, specific changes in the environment in which the fish was living can be more clearly resolved.

These few examples are just a beginning. The enormous potential of SIMS micro-analysis to contribute to studies of palaeoecology and archaeology has yet to be fully explored.

\section{Acknowledgements}

This research was supported by ARC Discovery grant P0664144 (Grün et al.) Microanalyis of human fossils: new insights into age, diet and migration and ARC Linkage grant LP0775058 (Grün et al.) Environmental Evolution of the Willandra Lakes World Heritage Area. Thank you to the traditional owners of the Willandra Lakes region for supporting this research. Marie Balasse and Andrew B. Smith provided the steenbok tooth.

\section{Appendix A. Supplementary material}

Supplementary data associated with this article can be found, in the online version, at doi:10.1016/j.jas.2012.05.002.

\section{References}

Allen, G.R., Midgley, S.H., Allen, M., 2002. Field Guide to the Freshwater Fishes of Australia. CSIRO Publishing, Collingwood.

Anderson, J.R., Morison, A.K., Ray, D.J., 1992. Validation of the use of thin-sectioned otoliths for determining the age and growth of golden perch, Macquaria ambigua (Perciformes, Percichthidae), in the lower Murray-Darling Basin, Australia. Australian Journal of Marine and Freshwater Research 43, 1103-1128.

Andrus, C.F.T., Crowe, D.E., 2002. Alteration of otolith aragonite: effects of prehistoric cooking methods on otolith chemistry. Journal of Archaeological Science 29, 291-299.
Ashford, J., Jones, J., 2007. Oxygen and carbon stable isotopes in otolith records of Patagonian toothfish (Dissostichus eleginoides). Geochimica et Cosmochimica Acta 71, 87-94.

Aubert, M., Grün, R., Eggins, S., Moncel, M.H., 2007. High resolution elemental and isotopic distribution in fossil teeth: implications for diet and migration. XVI INQUA Congress, 28 July-3 August, Cairns, Australia, Abstract 0880. Quaternary International 167-168, 17-18.

Balasse, M., 2003. Potential biases in sampling design and interpretation of intratooth analysis. International Journal of Osteoarchaeology 13, 3-10.

Balasse, M., Ambrose, S.H., Smith, A.B., Price, T.D., 2002. The seasonal mobility model for prehistoric herders in the south-western cape of South Africa assessed by isotopic analysis of sheep tooth enamel. Journal of Archaeological Science 29, 917-932.

Balasse, M., Smith, A.B., Ambrose, S.H., Leigh, S.R., 2003. Determining sheep birth seasonality by analysis of tooth enamel oxygen isotope ratios: the late stone age site of Kasteelberg (South Africa). Journal of Archaeological Science 30, 205-215.

Balme, J., 1983. Prehistoric fishing in the lower Darling, western New South Wales In: Grigson, C., Clutton-Brock, J. (Eds.), Animals and Archaeology. Shell Middens, Fishes and Birds, BAR International Series 183, vol. 2. British Archaeological Reports, Oxford, pp. 19-32.

Béarez, P., Dufour, E., Chauchat, C., Crédou, J., 2011. Les paijaniens de la Pampa de los Fósiles (Nord-Pérou, 11 000-8 000 BP): pêcheurs, chasseurs ou opportunistes? Peuplements et préhistoire en Amériques sous la direction de Denis Vialou. Editions du Comité des travaux historiques et scientifiques, Collection Documents historiques n 28, 233-246.

Bocherens, H., Rousseau, L., 2008. Chapitre 8: Le cadre environnemental des occupations humains. Isotopes sur grands mammifères et plancher stalagmitique. In: Moncel, M.-H. (Ed.), 2008. Le site de Payre, vol. 46. Mémoire de la Société préhistorique française, pp. 113-122.

Boljkovac, K., 2009. In situ SHRIMP $\delta 180$ and laser ablation ICP-MS Sr/Ca and 87Sr/ $86 \mathrm{Sr}$ measurements in fossil otoliths for palaeoclimate reconstructions at the Willandra Lakes World Heritage Area, Unpublished Honours thesis, Research School of Earth Sciences, The Australian National University.

Bowler, J.M., 1998. Willandra Lakes revisited: environmental framework for human occupation. Archaeology in Oceania 33, 120-155.

Bowler, J.M., Magee, J.W., 2000. Redating Australia's oldest human remains: a sceptic's view. Journal of Human Evolution 38, 719-726.

Bowler, J.M., Price, D.M., 1998. Luminesence dates and stratigraphic analyses at Lake Mungo: review and new perspectives. Archaeology in Oceania 33, 156-168.

Bowler, J.M., Thorne, A.G., 1976. Human remains from Lake Mungo: discovery and excavation of Lake Mungo III. In: Kirk, R.L., Thorne, A.G. (Eds.), The Origin of the Australians. Australian Institute of Aboriginal Studies, Canberra, pp. 127-138.

Bowler, J.M., Jones, R., Allen, H., Thorne, A.G., 1970. Pleistocene human remains from Australia: a living site and human cremation from Lake Mungo, western New South Wales. World Archaeology 2, 39-60.

Bowler, J.M., Johnston, H., Olley, J.M., Prescott, J.R., Roberts, R.G., Shawcross, W., Spooner, N.A., 2003. New ages for human occupation and climatic change at Lake Mungo, Australia. Nature 421, 837-840.

Campana, S.E., 1999. Chemistry and composition of fish otolith: pathways, mechanisms and applications. Marine Ecology Progress Series 188, 263-297.

Campana, S.E., Neilson, J.D., 1985. Microstructure of fish otoliths. Canadian Journal of Fisheries and Aquatic Sciences 42, 1014-1032.

Carpenter, S.J., Erickson, J.M., Holland Jr., F.D., 2003. Migration of a Late Cretaceous fish. Nature 423, 70-74.

Cerling, T.E., Sharp, Z.D., 1996. Stable carbon and oxygen isotope analysis of fossil tooth enamel using laser ablation. Palaeogeography, Palaeoclimatology and Palaeoecology 126, 173-186.

Chauchat, C., 1988. Early hunter-gatherers on the Peruvian coast. In: Keatinge, R.W. (Ed.), Peruvian Prehistory. An Overview of Pre-Inca Society. Cambrigde University Press, pp. 41-71.

Chauchat, C., Wing, E., Lacombe, J.-P., Demars, P.-Y., Uceda, S., et Deza, C., 1992. Préhistoire de la côte nord du Pérou. Le Paijanien de Cupisnique. Cahiers du Quaternaire, CNRS Éditions, pp. 1-391.

Chauchat, C., Pelegrin, J., Gálvez-Mora, C., Becerra-Urteago, R., et Esquerre-Alva, R 2004. Projectile Point Technology and Economy. A Case Study from Paiján, North Coastal Peru. Texas A\&M University Press, 126 pp.

Clement, S.W.J., Compston, W., Newstead, G., 1977. Design of a large, high resolution ion microprobe. Unpublished abstract from the First International Conference on Secondary Ion Mass Spectrometry, Münster.

Cole, J.E., Dunbar, R.B., McClanahan, T.R., Muthiga, N.A., 2000. Tropical Pacific forcing of decadal SST variability in the western Indian Ocean over the past two centuries. Science 287, 617-619.

Combier, J., 1967. Le Paléolithique de l'Ardèche dans son cadre paléoclimatique. Mémoire 4, Delmas, Bordeaux.

Dean, M.C., Shellis, R.P., 1998. Observations on stria morphology in the lateral enamel of pongo, hylobates and proconsul teeth. Journal of Human Evolution $35,401-410$.

Debard, E., 1988. Le Quaternaire du Bas-Vivarais d'après l'étude des remplissages d'avens, de porches de grottes et d'abris sous roche. In: Dynamique sédimentaire, paléoclimatologie et chronologie, vol. 13. Document des laboratoires de géologie. Université de Lyon.

Douglas, J.W., Gooley, G.J., Ingram, B.A., 1994. Trout Cod, Maccullochella macquariensis (Cuvier) (Pisces: Percichthyidae), Resource Handbook and Research and Recovery Plan, vol. 98. Fisheries Research Institute, Snobs Creek, Victoria. 
Driessens, F.C.M., Verbeeck, R.M.H., 1990. Biominerals. CRC, Boca Raton.

Dufour, E., Gerdeaux, D., 2007. Summer depth positioning of whitefish (Coregonus lavaretus) in Lake Annecy inferred from oxygen thermometry of otoliths. In: Jankun, M., Brzuzan, P., Hliwa, P., Luczynski, M. (Eds.), Biology and Managemen of Coregonid Fishes. Archiv für Hydrobiologie Special Issues in Advanced Limnology, vol. 60, pp. 195-204.

Dufour, E., Cappetta, H., Denis, A., Dauphin, Y., Mariotti, A., 2000. La diagenèse des otolithes par la comparaison des données microstructurales, minéralogiques et géochimiques: application aux fossiles du Pliocène du Sud-Est de la France. Bulletin de la Société Géologique de France 171, 521-532.

Dufour, E., Hook, T.O., Patterson, W.P., Rutherford, E.S., 2008. High-resolution isotope analysis of young alewife Alosa pseudoharengus otoliths: assessment of temporal resolution and reconstruction of habitat occupancy and therma history. Journal of Fish Biology 73, 2434-2451.

Eggins, S.M., Kinsley, L.K., Shelley, J.M.G., 1998a. Deposition and element fractionation processes occurring during atmospheric pressure laser sampling for analysis by ICPMS. Applied Surface Science 127-129, 278-286.

Eggins, S.M., Rudnick, R.L., McDonough, W.F.M., 1998b. The composition of peridotites and their minerals, a laserablation ICPMS study. Earth and Planetary Science Letters 154, 53-71.

Eiler, J., Stolper, E.M., McCanta, M.C., 2011. Intra and Intercrystalline oxygen isotope variations in minerals from basalts and peridotites. Journal of Petrology 10, $1-21$.

Elsdon, T.S., Gillanders, B.M., 2002. Interactive effects of temperature and salinity on otolith chemistry: challenges for determining environmental histories of fish. Canadian Journal of Fisheries and Aquatic Sciences 59, 1796-1808.

Elsdon, T.S., Wellls, B.K., Campana, S.E., Gillanders, B.M., Jones, C.M., Limburg, K.E. Secor, D.H., Thorrold, S.R., Walther, B.D., 2008. Otolith chemistry to describe movements and life-history parameters of fishes: hypotheses, assumptions, limitations and inferences. Oceanography and Marine Biology: An Annual Review 46, 297-330.

Faure, G., Mensing, T., 2005. Isotopes - Principles and Applications, third ed. John Wiley, New Jersey.

Fearne, J.M., Elliot, J.C., Wong, F.S.L., Davis, G.R., Boyde, A., Jones, S.J., 1994. Deciduous enamel defects in low birthweight children: correlated X-ray microtomographic and backscattered electron imaging study of hypoplasia and hypomineralization. Anatomy and Embryology 189, 375-381.

Feranec, R.S., MacFadden, B.J., 2000. Evolution of the grazing niche in Pleistocene mammals from Florida: evidence from stable isotopes. Palaeogeography, Palaeoclimatology, Palaeoecology 162, 155-169.

Fowler, A.J., Campana, S.E., Jones, C.M., Thorrold, S.R., 1995. Experimental assessment of the effect of temperature and salinity on elemental composition of otoliths using laser ablation ICPMS. Canadian Journal of Fisheries and Aquatic Sciences 52, 1421-1430.

Fraser, R., Grün, R., Privat, K., Gagan, M.K., 2008. Stable-isotope microprofiling of wombat tooth enamel records seasonal changes in vegetation and environmental conditions in eastern Australia. Palaeogeography, Palaeoclimatology and Palaeoecology 269, 66-77.

Fricke, H.C., O'Neil, J.R., 1996. Inter- and intra-tooth variation in the oxygen isotope composition of mammalian tooth enamel phosphate: implications for palaeoclimatological and palaeobiological research. Palaeogeography, Palaeoclimatology, Palaeoecology 126, 91-99.

Fricke, H.C., Clyde, W.C., O'Neil, J.R., 1998. Intra-tooth variations in $\delta^{18} \mathrm{O}\left(\mathrm{PO}_{4}\right)$ of mammalian tooth enamel as a record of seasonal variations in continental climate variables. Geochimica et Cosmochimica Acta 62, 1839-1850.

Gat, J.R., 1996. Oxygen and hydrogen isotopes in the hydrologic cycle. Annual Review of Earth and Planetary Sciences 24, 225-262.

Gibson, J.J., Sadek, M.A., Stone, D.J.M., Hughes, C.E., Hankin, S., Cendon, D.I. Hollins, S.E., 2008. Evaporative isotope enrichment as a constraint on reach water balance along a dryland river. Isotopes in Environmental and Health Studies 44 (1), 83-98.

Grossman, E.L., Ku, T.-L., 1986. Oxygen and carbon isotope fractionation in biogenic aragonite: temperature effects. Chemical Geology: Isotope Geoscience Section $59,59-74$.

Grün, R. Spooner, N.A., Thorne, A., Mortimer, G., Simpson, J.J., McCulloch, M. Taylor, L., Curnoe, D., 2000. Age of the Lake Mungo 3 skeleton, reply to Bowler \& Magee and to Gillespie \& Roberts. Journal of Human Evolution 38, 733-741.

Grün, R., Aubert, M., Joannes-Boyau, R., Moncel, M.H., 2008. High resolution analysis of uranium and thorium concentrations as well as U-series isotope distributions in a Neanderthal tooth from Payre using laser ablation ICP-MS. Geochimica et Cosmochimica Acta 72, 5278-5290.

Hanson, N.N., Wurster, C.M., Todd, C.D., EIMF, 2010. Comparison of secondary ion mass spectrometry and micromilling/continuous flow isotope ratio mass spectrometry techniques used to acquire intra-otolith delta O-18 values of wild Atlantic salmon (Salmo salar). Rapid Communications in Mass Spectrometry 24, 2491-2498.

Hilson, S., 1986. Teeth. Cambridge University Press, New York.

Huxham, M., Kimani, E., Newton, J., Augley, J., 2007. Stable isotope records from otoliths as tracers of fish migration in a mangrove system. Journal of Fish Biology 70, 1554-1567.

Iacumin, P., Bocherens, H., Mariotti, A., Longinelli, A., 1996. Oxygen isotope analyses of co-existing carbonate and phosphate in biogenic apatite: a way to monitor diagenetic alteration of bone phosphate? Earth and Planetary Science Letters 142, 1-6.

Ickert, R.B., Hiess, J., Williams, I.S., Holden, P., Ireland, T.R., Lanc, P., Schram, N., Foster, J.J., Clement, S.W., 2008. Determining high precision, in-situ, oxygen isotope ratios with a SHRIMP II: analyses of MPI-DING silicate-glass reference materials and zircon from contrasting granites. Chemical Geology 257, 114-128.

International Atomic Energy Agency, 1992. Statistical Treatment of data on environmental isotopes in Precipitation, Technical Reports Series 331, IAEA, Vienna.

Ireland, T.R., 1995. Ion microprobe mass spectrometry: techniques and applications in cosmochemistry, geochemistry, and geochronology. In: Hyman, M., Rowe, M. (Eds.), 1995. Advances in Analytical Geochemistry, vol. 2, pp. 1-118.

Ireland, T.R., Clement, S.W.J., Compston, W., Foster, J.J., Holden, P., Jenkins, B. Lanc, P., Schram, N., Williams, I.S., 2008. Development of SHRIMP. Australian Journal of Earth Sciences 55, 937-954

Ivany, L.C., Patterson, W.P., Lohmann, K.C., 2000. Cooler winters as a possible cause of mass extinctions at the Eocene/Oligocene boundary. Nature 407, $887-890$.

Jones, A.M., Iacumin, P., Young, E.D., 1999. High-resolution $\delta 180$ analysis of tooth enamel phosphate by isotope ratio monitoring gas chromatography mass spectrometry andultraviolet laser fluorination. Chemical Geology 153, 241-248.

Kalish, J.M., 1991. Determinants of otolith chemistry: seasonal variation in the composition of blood plasma, endolymph and otoliths of bearded rock cod Pseudophycis barbatus. Marine Ecology Progress Series 74, 137-159.

Kalish, J.M., 1992. Formation of stress-induced chemical check in fish otoliths. Journal of Experimental Marine Biology and Ecology 162, 265-277.

Kawakami, Y., Mochioka, N., Morishita, K., Tajima, T., Nakagawa, H., Toh, H., Nakazono, A., 1998. Factors influencing otolith strontium/calcium ratios in Anguilla japonica elvers. Environmental Biology of Fishes 52, 299-303.

Kelly, T.E., Grün, R., Mortimer, G., Aubert, M., Woodhead, J., Eggins, S., Thönessen, M., Maureille, B., 2007. Sr isotope tracing at the Neanderthal site of Les Pradelles, Charente, France. XVII INQUA Congress, 28 July-3 August 2007, Cairns, Australia, Abstract 0397. Quaternary International 167-168, 203.

Kita, N.t., Ushikubo, T., Fu, B., Valley, J.W., 2009. High precision SIMS oxygen isotope analysis and the effect of sample topography. Chemical Geology 264, 43-57.

Kohn, M.J., 2004. Comment: tooth enamel mineralization in ungulates: implications for recovering a primary isotopic time-series, by B.H. Passey \& T.E. Cerling (2002). Geochimica et Cosmochimica Acta 68 (2), 403-405.

Kohn, M.J., Schoeninger, M.J., Valley, J.W., 1996. Herbivore tooth oxygen isotope compositions: effects of diet and physiology. Geochimica et Cosmochimica Acta 60, 3889-3896

Kohn, M.J., Schoeninger, M.J., Barker, W.W., 1999. Altered states: effects of diagenesis on fossil tooth chemistry - application to paleotemperature determination. Geochimica et Cosmochimica Acta 63, 2737-2747.

Kozdon, R., Ushikubo, T., Kita, N.T., Valley, J.W., 2009. Intratest oxygen isotope variability in the planktonic foraminifer $N$. pachyderma: real vs. apparent vital effects by ion microprobe. Chemical Geology 258, 327-337.

Land, L.S., Lundelius, E.L.J., Valastro, S.J., 1980. Isotopic ecology of deer bones. Palaeogeography, Palaeoclimatology, Palaeoecology 32, 143-151.

Lécuyer, C., Picard, S., Garcia, J.-P., Sheppard, S.M.F., Grandjean, P., Dromart, G., 2003. Thermal evolution of Tethyan surface waters during the Middle-Late Jurassic: evidence from $\delta^{18} \mathrm{O}$ values of marine fish teeth. Paleoceanography 18, 1076-1091.

Lin, S.H., Chang, C.W., Iizuka, Y., Tzeng, W.N., 2007. Salinities, not diets, affect strontium/calcium ratios in otoliths of Anguilla japonica. Journal of Experimental Marine Biology and Ecology 341, 254-263.

Longerich, H.P., Jackson, S.E., Gunther, D., 1996. Laser ablation inductively coupled plasma mass spectrometric transient signal data acquisition and analyte concentration calculation. Journal of Analytical Atomic Spectrometry 11, 899-904.

Longinelli, A., 1984. Oxygen isotopes in mammal bone phosphate: a new tool for paleohydrological and paleoclimatological research? Geochimica et Cosmochimica Acta 48, 385-390.

Luz, B., Kolodny, Y., 1985. Oxygen isotope variations in phosphate of biogenic apatites, IV. Mammal teeth and bones. Earth and Planetary Science Letters 75, 29-36.

Luz, B., Kolodny, Y., Horowitz, M., 1984. Fractionation of oxygen isotopes between mammalian bone-phosphate and environmental drinking water. Geochimica et Cosmochimica Acta 48, 1689-1693.

Macchiarelli, R., Bondioli, L., Debénath, A., Mazurier, A., Tournepiche, J.-F., Birch, W., Dean, C., 2006. How Neanderthal molar teeth grew. Nature 444, 748-751.

Macho, G.A., Jiang, Y., Spears, I.R., 2003. Enamel microstructure - a truly threedimensional structure. Journal of Human Evolution 45, 821-830.

Mallen-Cooper, M., Stuart, I.G., 2003. Age, growth and non-flood recruitment of two potamodromous fishes in a large semi-arid/temperate river system. River Research and Applications 19, 697-719.

Moncel, M.H., 2003. L'exploitation de l'espace et la mobilité des groupes humains au travers des assemblages lithiques à la fin du Pléistocène moyen et au début du Pléistocène supérieur. La moyenne vallée du Rhône entre Drôme et Ardèche. BAR International Series S1184, 179.

Moncel, M.H., 2004. Continuité et variabilité des occupations humaines à la fin du Pléistocène moyen et au début du Pléistocène supérieur (stades isotopiques 9 à 3). L'exemple de la moyenne vallée du Rhône (France). In: Conard, N.J. (Ed.) Settlement Dynamics of the Middle Palaeolithic and Middle Stone Age II. Kerns Verlag, Tübingen, pp. 295-317.

Moncel, M.H., Condemi, S., 1996. Découverte de dents humaines dans le site Paléolithique moyen de Payre (Ardèche, France). In: Comptes rendus de l'Académie des sciences. Série II. Fascicule a, vol. 322. Sciences de la terre et des planètes, pp. 251-257. 
Moncel, M.H., Condemi, S., 1997. Des restes humains dans le site Paléolithique moyen ancien de Payre (Ardèche): dents et pariétal. Nouvelles découvertes de 1996. Bulletin de la Société préhistorique française 94/2, 168-171.

Moncel, M.H., Debard, E., Desclaux, E., Dubois, J.M., Lamarque, F., Patou-Mathis, M., Vilette, P., 2002. Le cadre de vie des hommes du Paléolithique moyen (stades isotopiques 6 et 5) dans le site de Payre (Rompon, Ardèche): d'une grotte à un abri-sous-roche effondré. Bulletin de la Société préhistorique française 99 (2), 249-275.

Moncel, M.H., Moigne, A.M., Combier, J., 2005. Pre-Neandertal behaviour during isotopic stage 9 and the beginning of stage 8 . New data concerning fauna and lithics in the different occupation levels of orgnac 3 (Ardèche, South-East France): occupation types. Journal of Archaeological Sciences 32, 1283-1301.

Munro, A.R., Gillanders, B.M., Elsdon, T.S, Crook, D.A., Sanger, A.C., 2008. Enriched stable isotope marking of juvenile golden perch (Macquaria ambigua) otoliths. Canadian Journal of Fisheries and Aquatic Sciences 65, 276-285.

Olley, J.M., Roberts, R.G., Yoshida, H., Bowler, J.M., 2006. Single-grain optical dating of grave-infill associated with human burials at Lake Mungo, Australia. Quaternary Science Reviews 25, 2469-2474.

Outridge, P.M., Chenery, S.R., Babaluk, J.A., Reist, J.D., 2002. Analysis of geological Sr isotope markers in fish otoliths with subannual resolution using laser ablationmulticollector-ICP mass spectrometry. Environmental Geology 42 (8), 891-899.

Passey, B.H., Cerling, T.E., 2006. In situ stable isotope analysis $(\delta 13 C, \delta 180)$ of very small teeth using laser ablation GC/IRMS. Chemical Geology 235, 238-249.

Patterson, W.P., 1999. Oldest isotopically characterized fish otoliths provide insight to Jurassic continental climate of Europe. Geology 27, 199-202.

Patterson, W.P., Smith, G.R., Lohmann, K.C., 1993. Continental paleothermometry and seasonality using the isotopic composition of aragonitic otoliths of freshwater fishes. In: Swart, P.K., Lohmann, K.C., McKenzie, J., Savin, S. (Eds.), Climate Change in Continental Isotopic Records. American Geophysical Union, Washington, D.C, pp. 191-215.

Pellegrini, M., Lee-Thorp, J.A., Donahue, R.E., 2011. Exploring the variation of the $\delta^{18} \mathrm{Op}$ and $\delta^{18} \mathrm{Oc}$ relationship in enamel increments. Palaeogeography, Palaeoclimatology, Palaeoecology 310, 71-83.

Podlesak, D.W. Torregrossa, A, Ehleringer, J.R. Dearing M.D. Passey, B.H Cerling, T.E., 2008. Turnover of oxygen and hydrogen isotopes in the body water, $\mathrm{CO}_{2}$, hair, and enamel of a small mammal. Geochimica et Cosmochimica Acta $72,19-35$.

Schuhmacher, M., Fernandes, F., De Chambost, E., 2004. Achieving high reproducibility isotope ratios with the Cameca IMS1270 in the multicollection mode. Applied Surface Science 231-232, 878-882.

Secor, D.H., Henderson-Arzapalo, A., Piccoli, P.M., 1995. Can otolith microchemistry chart patterns of migration and habitat utilization in anadromous fishes? Journal of Experimental Marine Biology and Ecology 192, 15-33.

Secor, D.H., Ohta, T., Nakayama, K., Tanaka, M., 1998. Use of otolith microanalysis to determine estuarine migration of Japanese sea bass Lateolabrax japonicus distributed in Ariake Sea. Fishery Science 64, 740-743.

Sharp, Z.D., Cerling, T.E., 1996. A laser GC-IRMS technique for in situ stable isotope analyses of carbonates and phosphates. Geochimica et Cosmochimica Acta 60, 2909-2916.

Sharp, Z.D., Cerling, T.E., 1998. Fossil isotope records of seasonal change and ecology: straight from the horse's mouth. Geology 26, 219-222.

Shephard, S., Trueman, C., Rickaby, R., Rogan, E., 2007. Juvenile life history of NE Atlantic orange roughy from otolith stable isotopes. Deep Sea Research 54 (1), 1221-1230.

Smith, C.E., 1998. Cellular and chemical events during enamel maturation. Critical Reviews in Oral Biology \& Medicine 9, 28-161.

Smith, T.M., Tafforeau, P., 2008. New visions of dental tissue research: tooth development, chemistry, and structure. Evolutionary Anthropology 17, 213-226.

Stuart-Williams, H.L.Q., Schwarz, H.P., 1997. Oxygen isotopic determination of climatic variation using phosphate from beaver bone, tooth enamel, and dentine. Geochimica et Cosmochimica Acta 61, 2539-2550.

Suga, S., 1982. Progressive mineralization pattern of developing enamel during the maturation stage. Journal of Dental Research 61, 1532-1542.
Suga, S., 1989. Enamel hypomineralization viewed from the pattern of progressive mineralization of human and monkey developing enamel. Advances in Dental Research 3, 188-198.

Surge, D., Walker, K.J., 2005. Oxygen isotope composition of modern and archaeological otoliths from the estuarine hardhead catfish (Ariopsis felis) and their potential to record low-latitude climate change. Palaeogeography, Palaeoclimatology, Palaeoecology 228, 179-191.

Thorne, A., Grün, R., Mortimer, G., Spooner, N.A., Simpson, J.J., McCulloch, M. Taylor, L., Curnoe, D., 1999. Australia's oldest human remains: age of the Lake Mungo 3 skeleton. Journal of Human Evolution 36, 591-612.

Thorrold, S.R., Campana, S.E., Jones, C.M., Swart, P.K., 1997. Factors determining $\delta^{13} \mathrm{C}$ and $\delta^{18} \mathrm{O}$ fractionation in aragonitic otoliths of marine fish. Geochimica et Cosmochimica Acta 61, 2909-2919.

Thresher, R.E., 1999. Elemental composition of otoliths as a stock delineator in fishers. Fisheries Research 43, 165-204.

Treble, P.C., Chappell, J., Gagan, M.K., McKeegan, K.D., Harrison, T.M., 2005. In situ measurement of seasonal delta 0-18 variations and analysis of isotopic trends in a modem speleothem from southwest Australia. Earth and Planetary Science Letters 33, 17-32.

Treble, P.C., Schmitt, A.K., Edwards, R.L., McKeegan, K.D., Harrison, T.M., Grove, M. Cheng, H., Wang, Y.J., 2007. High resolution secondary ionisation mass spectrometry (SIMS) delta O-18 analyses of Hulu Cave speleothem at the time of Heinrich event 1. Chemical Geology 238, 197-212.

Trotter, J.A., Williams, I.S., Barnes, C.R., Lecuyer, C., Nicoll, R.S., 2008. Did cooling oceans trigger Ordovician biodiversification? Evidence from conodont thermometry. Science 321, 550-554.

Valladas, H., Mercier, N., Ayliffe, L.K., Falguères, C., Bahain, J.J., Dolo, J.M., Froget, L., Joron, J.L., Masaoudi, H., Reyss, J.L., Moncel, M.H., 2008. Radiometric dates for the Middle Palaeolithic sequence of Payre (Ardèche, France). Quaternary Geochronology 3, 377-389.

Valley, J.W., Graham, C.M., Harte, B., Kinny, P., Eiler, J.M., 1998. Ion microprobe analysis of oxygen, carbon, and hydrogen isotope ratios. In: McKibben, M.A. et al. (Eds.), 1998. Reviews in Economic Geology, vol. 7. Society of Economic Geologists, pp. 73-98.

Wade, B.S., Kroon, D., 2002. Middle Eocene regional climate instability: evidence from the western North Atlantic. Geology 30, 1011-1014.

Weber, P.K., Bacon, C.R., Hutcheon, I.D., Ingram, B.L., Wooden, J.L., 2005, Ion microprobe measurement of strontium isotopes in calcium carbonate with application to salmon otoliths. Geochimica et Cosmochimica Acta 6, 1225-1239.

Weidel, B.C., Ushikubo, T., Carpenter, S.R., Kita, N.T. Cole, J.J., Kitchell, J.F., Pace, M.L Valley, J.W., 2007. Diary of a bluegill (Lempomis macrochirus): daily $\delta^{13} \mathrm{C}$ and $\delta^{18} \mathrm{O}$ records in otoliths by ion microprobe. Canadian Journal of Fisheries and Aquatic Sciences 64, 1641-1645.

Wiedemann, F.B., Bocherens, H., Mariotti, A., von den Driesch, A., Grupe, G., 1999 Methodological and archaeological implications of intra-tooth isotopic variations $\left(\delta^{13} \mathrm{C}, \delta^{18} \mathrm{O}\right)$ in herbivores from Ain Ghazal (Jordan, Neolithic). Journal of Archaeological Sciences 26, 697-704.

Wurster, C.H., Patterson, W.P., Cheatham, M.M., 1999. Advances in computer-based microsampling of biogenic carbonates. Computers in Geosciences 25, 1155-1162.

Wurster, C.M., Patterson, W.P., Stewart, D.J., Stewart, T.J., Bowlby, J.N., 2005. Therma histories, stress, and metabolic rates of chinook salmon in Lake Ontario: evidence from intra-otolith $\delta^{18} \mathrm{O}$ and $\delta^{13} \mathrm{C}$ values and energetics modeling. Canadian Journal of Fisheries and Aquatic Sciences 62, 700-713.

Zazzo, A., Lécuyer, C., Sheppard, S.M.F., Grandjean, P., Mariotti, A., 2004. Diagenesis and reconstruction of paleoenvironments: a method to restore original $\delta^{18} 0$ values of carbonate and phosphate from fossil tooth enamel. Geochimica et Cosmochimica Acta 68, 2245-2258.

Zazzo, A., Balasse, M., Patterson, W.P., 2005. High-resolution $\delta^{13} \mathrm{C}$ intratooth profiles in bovine enamel: implications for mineralization pattern and isotopic attenuation. Geochimica et Cosmochimica Acta 69 (14), 3631-3642.

Zimmerman, C.E., 2005. Relationship of otolith strontium-to-calcium ratios and salinity: experimental validation for juvenile salmonids. Canadian Journal of Fisheries and Aquatic Sciences 62, 88-97. 